\title{
Distribution kinetics of trophic single doses of methylmercury, tributyltin, and corresponding inorganic ions in the starfish Leptasterias polaris
}

\author{
Claude Rouleau ${ }^{1}$, Emilien Pelletier ${ }^{2, *}$, Hans Tjälve ${ }^{3}$ \\ ${ }^{1}$ Université du Québec à Rimouski, Département d'océanographie, 310 Allée des Ursulines, \\ Rimouski, Québec, Canada G5L 3A1 \\ ${ }^{2}$ Université du Québec, INRS-Océanologie, 310 Allée des Ursulines, Rimouski, Québec, Canada G5L 3A1 \\ ${ }^{3}$ Swedish University of Agricultural Sciences, Department of Toxicology and Pharmacology, \\ Faculty of Veterinary Medicine, Biomedicum Box 573, S-751 23 Uppsala, Sweden
}

\begin{abstract}
Whole-body autoradiography (WBARG) and a multicompartmental model were used to describe, quantify, and compare the distribution kinetics over $48 \mathrm{~h}$ of trophic single doses of methylmercury (MeHg), tributyltin (But 3 Sn), and the corresponding inorganic ions, $\mathrm{Hg}$ (II) and $\mathrm{Sn}(\mathrm{IV}$ ), in starfish Leptasterias polaris. The food consisted of homogenized mussel flesh spiked with $2.5 \mathrm{nmol} \mathrm{g}$ of ${ }^{203} \mathrm{HgCl}_{2}, \mathrm{CH}_{3}{ }^{203} \mathrm{HgCl}^{113} \mathrm{SnCl}_{4}$ or (But) ${ }_{3}{ }^{113} \mathrm{SnCl}$. The model presented differs from conventional multicompartmental pharmacokinetic models as compartment contents are related to the whole-body content rather than the concentration of metal species in a reference tissue. WBARG indicated that transfer of labelled compounds from the stomach (Compartment E) to pyloric caeca (Compartment C), and from pyloric caeca to the rest of the starfish (coelomic fluid, gonads, body wall, podia; Compartment R) proceeded mainly by transport via the pyloric ducts and by diffusion in the coelomic fluid, respectively, with a negligible contribution from the haemal system. Pyloric caeca were the main sites of accumulation for inorganic $\mathrm{Hg}$ and $\mathrm{Sn}$ (61 to $63 \%$ of total content) at steady-state while MeHg was more evenly distributed, each compartment accounting for one-third of the whole-body content. But ${ }_{3} \mathrm{Sn}$ content of starfish also tended to be more homogeneously distributed between compartments. Transfer of $\mathrm{MeHg}$ (rate constant $\alpha_{1}=0.208 \mathrm{~h}^{-1}$ ) from the stomach to pyloric caeca proceeded at a rate similar to inorganic $\mathrm{Hg}(\mathrm{II})$ and $\mathrm{Sn}(\mathrm{IV})\left(\alpha_{1}=0.196\right.$ and $0.178 \mathrm{~h}^{-1}$, respectively) and was assumed to be mainly a passive process associated with food transport. However, MeHg was transfered at a faster rate $\left(\alpha_{2}=\right.$ $0.099 \mathrm{~h}^{-1}$ ) from the pyloric caeca to the rest of the individual (coelomic fluid, gonads, body wall, podia) than inorganic $\mathrm{Hg}$ (II) $\left(\alpha_{2}=0.061 \mathrm{~h}^{-1}\right)$, this effect being associated to the facility of $\mathrm{MeHg}$ to cross biological membranes. But $3 \mathrm{Sn}$ distribution kinetic was the slowest $\left(\alpha_{1}=0.071 \mathrm{~h}^{-1}\right.$ and $\left.\alpha_{2}=0.017 \mathrm{~h}^{-1}\right)$. This result may be related to the strong binding capacity of $\mathrm{But}_{3} \mathrm{Sn}$ towards biological ligands and its low water solubility, coupled to other physical properties like sterical hindrance. Although organ distributions of $\mathrm{MeHg}$ and $\mathrm{But}_{3} \mathrm{Sn}$ at steady-state were rather similar, their kinetics were radically different, allowing a clear distinction between the 2 organometals. This finding enhances the necessity to consider the contaminant uptake problem from the point of view of both thermodynamic and kinetic approaches. The model developed in this work allowed the distinction between 2 transfer modes differentiated by their own chemical mechanisms. Such a model could be used for further studies on the distribution kinetics of trace metals, organometals, and other substances (like nutrients) in aquatic and terrestrial invertebrates.
\end{abstract}

KEY WORDS: Mercury - Methylmercury - Tin - Tributyltin - Distribution - Kinetic - Food - Starfish Leptasterias polaris

\section{INTRODUCTION}

Among organometallic compounds of particular environmental concern, methylmercury (MeHg) and

-Addressee for correspondence;

E-mail: emilien_pelletier@uqar.uquebec.ca tributyltin ( $\mathrm{But}_{3} \mathrm{Sn}$ ) are the best studied species. $\mathrm{MeHg}$ is highly toxic and has been found to be the cause of several mass human poisonings in recent decades (Fujiki \& Tajima 1992). Because of its ease of accumulation and its biological persistence, it is the main species of mercury found in aquatic animals (Bloom 1992). Environmental problems caused by $\mathrm{But}_{3} \mathrm{Sn}$ arise 
mainly from its use in anti-fouling paints which release But $_{3} \mathrm{Sn}$ directly into water (Clark et al. 1988). Very low But $_{3} \mathrm{Sn}$ concentrations (10 to $20 \mathrm{ng} \mathrm{l}^{-1}$ ) can have sublethal effects on aquatic fauna (Smith \& McVeagh 1991), and although many countries have regulated the use of tin anti-fouling paints, recent measurements showed that $\mathrm{But}_{3} \mathrm{Sn}$ concentrations in water remain high in many locations (Smith \& McVeagh 1991, Dowson et al. 1992). Many studies have been conducted on the uptake of $\mathrm{MeHg}, \mathrm{But}_{3} \mathrm{Sn}$, and the related inorganic ions, $\mathrm{Hg}(\mathrm{II})$ and $\mathrm{Sn}$ (IV), in aquatic organisms (Laughlin et al. 1986a, Zuolian \& Jensen 1989, Riisgård \& Hansen 1990, Rouleau et al. 1992). However, most reports described their accumulation and distribution in different organs and tissues at different exposure periods with no attempt to fit the data to an appropriate kinetic model allowing the calculation of exchange rates between organs and tissues.

The uptake rate of metal species from water, food or sediment can be characterized by a simple kinetic model using monoexponential equations to describe exchanges between the source of metal and the animal considered as a whole (Bertram \& Brooks 1986, Glynn 1991, Hare et al. 1991). However, the body burden of a contaminant in an animal does not always behave as a kinetically homogeneous unit due to certain chemical and physiological phenomena (such as the firm binding of metal atoms to cell components or the slower perfusion rate of some tissues) (Spacie \& Hamelink 1985). Thus, more complex models are needed to describe the uptake and the distribution of metals in aquatic animals

Pharmacokinetic multi-compartmental models have been applied in the field of aquatic toxicology to study the absorption, distribution, and excretion kinetics of chemicals in fish (Barron et al. 1990). A compartment represents a group of tissues that are kinetically indistinguishable for a particular chemical. The amount $Q$ of a chemical in a compartment $i$ is related to its concentration in a reference tissue, $C_{r}$ by a proportionality constant called the apparent volume of distribution, $V$. and is given by the expression

$$
V_{i}=Q_{i} / C_{r}
$$

while material exchange between compartments is characterized by a first order rate constant, $k_{i}$, and a clearance constant, $\mathrm{Cl}_{i}$, related to one another by

$$
\mathrm{Cl}_{1}=k_{1} V_{i}
$$

Blood is generally used as a reference tissue because of its ease of collection and its ubiquitous contact with all tissues (Barron et al. 1990). In spite of the increasing use of the pharmacokinetic approach in environmental studies (Barron et al. 1993), pharmacokinetic compartmental models have not yet been used to describe distribution kinetics of metal species between organs and tissues of marine invertebrates such as crustaceans and echinoderms. Furthermore, no previous studies have simultaneously compared kinetic parameters and distribution of $\mathrm{MeHg}$ and $\mathrm{But}_{3} \mathrm{Sn}$ in a given aquatic animal under given environmental conditions as a function of their physical and chemical properties. To fill this gap, we compared the uptake and the distribution kinetics of these metal species in Leptasterias polaris, a 6-armed starfish widely distributed in the St. Lawrence Gulf and Estuary (Himmelman \& Dutil 1991). L. polaris has been used as a biological model in our laboratory in long-term trophic transfer studies of $\mathrm{MeHg}$ (Pelletier \& Larocque 1987) and $\mathrm{But}_{3} \mathrm{Sn}$ (Mercier et al. 1994). From these experiments, it was evident that $\mathrm{MeHg}$ and $\mathrm{But}_{3} \mathrm{Sn}$ content of starfish did not behave as a kinetically homogeneous unit, thus pointing out the necessity for a multicompartmental model to adequately describe distribution kinetics of these compounds within this marine invertebrate. However, we needed to find a suitable reference tissue prior to the use of a pharmacokinetic model. As most starfish, including $L$. polaris, have a reduced circulatory system (Ferguson 1982) too small and diffuse to be used for this purpose, we developed a model using the whole-body content of the studied compound as the reference instead of its concentration in a reference tissue. The model has then been applied to characterize the $48 \mathrm{~h}$ distribution kinetics of trophic single doses of labelled $\mathrm{MeHg}, \mathrm{But}_{3} \mathrm{Sn}$, and corresponding inorganic ions, $\mathrm{Hg}(\mathrm{II})$ and $\mathrm{Sn}(\mathrm{IV})$, into the starfish L. polaris.

\section{MATERIAL AND METHODS}

Experiments. Starfish weighing $95 \pm 39 \mathrm{~g}(\mathrm{n}=128$, size range 40 to $240 \mathrm{~g}$ ) were caught at Pointe-au-Père harbour, in the St. Lawrence Estuary, in May to June 1991 and 1992. Before experiments, specimens were kept in running seawater and fed ad libitum with live blue mussels. Starfish were acclimated for $3 \mathrm{~d}$ to laboratory conditions prior to experiments ( $\mathrm{S}=25.9 \pm 0.8 \%$, $\mathrm{T}=5 \pm 1^{\circ} \mathrm{C}$ ). The food consisted of homogenized mussel flesh contaminated with $2.5 \mathrm{nmol} \mathrm{g}^{-1}$ of ${ }^{203} \mathrm{Hg}(\mathrm{II})$, $\mathrm{CH}_{3}{ }^{203} \mathrm{Hg}(\mathrm{II}),{ }^{113} \mathrm{Sn}(\mathrm{IV})$ or $\mathrm{But}_{3}{ }^{113} \mathrm{Sn}(\mathrm{IV})$, corresponding to $0.5 \mu \mathrm{g} \mathrm{Hg} \mathrm{g}^{-1}$ or $0.3 \mu \mathrm{g} \mathrm{Sn} \mathrm{g}^{-1}$. Labelled ${ }^{203} \mathrm{HgCl}_{2}$ in

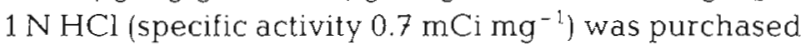
from Amersham. Labelled $\mathrm{CH}_{3}{ }^{203} \mathrm{HgCl}$ was synthesized from radioactive inorganic mercury according to Toribara (1985). Inorganic ${ }^{113} \mathrm{Sn}(\mathrm{IV})$ was purchased from Amersham and NEN-Dupont (specific activity 2.9 and $13.5 \mathrm{mCi} \mathrm{mg}^{-1}$, respectively) as hexachlorostannate dissolved in $6 \mathrm{~N} \mathrm{HCl}$. Labelled tributyltin chloride $\left(\mathrm{But}_{3}{ }^{113} \mathrm{SnCl}\right)$ was synthesized according to 
Rouleau (1994). Briefly, inorganic ${ }^{113} \mathrm{Sn}$ (IV) was extracted in diethylether and reacted with ButMgCl to give $\mathrm{But}_{4}{ }^{113} \mathrm{Sn}$. Labelled tributyltin chloride was then obtained from the following reaction:

$$
\mathrm{But}_{4}{ }^{113} \mathrm{Sn}+\mathrm{HgCl}_{2} \stackrel{\mathrm{MeOH} 85 \%}{\longrightarrow} \mathrm{But}_{3}{ }^{113} \mathrm{SnCl}+\mathrm{ButHgCl}
$$

Tributyltin was isolated from the reaction mixture by successive extractions with hexane and aqueous $\mathrm{Na}_{2} \mathrm{~S}_{2} \mathrm{O}_{3}$ (to remove butylmercury chloride) and dissolved in ethanol prior to use. Radioactive tributyltin chloride obtained was $98 \%$ pure (as confirmed by thin layer chromatography)

Contaminated food was directly injected through the mouth into the stomach of starfish $(1 \mathrm{~g}$ food $/ 100 \mathrm{~g}$ wet body weight, $\pm 10 \%$ ). After food injection, starfish were placed in $4 \mathrm{l}$ beakers containing $3.5 \mathrm{l}$ of UV-sterilized and aerated natural seawater and allowed to stand for $1,2,4,6,8,12,16,20,24,36$ or $48 \mathrm{~h}$. Three starfish were used at each sampling time. The starfish were briefly rinsed in clean seawater, coelomic fluid was sampled with a syringe, and mouth, stomach, pyloric caeca, gonads, podia, and body wall were dissected out. Tissue samples were weighed and their radioactivity determined by gamma counting with a LKB 1272 Clinigamma ${ }^{\circledR}$ counter. Rectal caeca and stomachal content were not separated from stomach tissues but counted with it. Tissues constituting the mouth were those associated with the opening. The podia were counted with the skeletal plates of ambulacral grooves and ampulla attached. The axial gland was dissected and counted separately. Radioactivity counts were corrected for the background level and the decay of isotopes and converted to nmol of $\mathrm{Hg}$ or Sn. Mercury and tin contents of organs and tissues of starfish calculated from radioactivity measurements were used to calculate experimental parameters of compartmental models.

At $t=6,16$ and $48 \mathrm{~h}, 2$ additional starfish were used for whole-body autoradiography (WBARG) according to the technique developed by Ullberg et al. (1982). Leptasterias polaris individuals were embedded in a carboxymethyl cellulose gel and frozen in a slurry of hexane and dry ice. Embedded starfish were sectioned $(40 \mu \mathrm{m})$ on tape $(3 \mathrm{M}$, type 810$)$ in the radial or transversal planes with a specially designed cryomicrotome (LKB $2250 \mathrm{PMV}$ ) at $-20^{\circ} \mathrm{C}$. Sections were then freezedried at $-20^{\circ} \mathrm{C}$ for $48 \mathrm{~h}$ and applied to a regular $\mathrm{X}$-ray film (AGFA Structurix) for ${ }^{203} \mathrm{Hg}$ or Hyperfilm- ${ }^{3} \mathrm{H}$ (Amersham) for ${ }^{113} \mathrm{Sn}$. After a 4 mo exposure at $-20^{\circ} \mathrm{C}$, the films were processed as recommended by the manufacturer. Images of whole-body autoradiograms shown in Figs. 6 to 8 were obtained by printing on photographic paper Ilfospeed Multigrade II.

Hg speciation in the pyloric caeca of starfish 24 and $48 \mathrm{~h}$ after the injection of MeHg-contaminated food was determined. Approximately $1 \mathrm{~g}$ of pyloric caeca was sampled from each individual. These samples were digested in $5 \mathrm{ml}$ of $45 \%(\mathrm{w} / \mathrm{v}) \mathrm{KOH}$ and $1 \mathrm{ml}$ of $1 \%(\mathrm{w} / \mathrm{v})$ cysteine for $1 \mathrm{~h}$ at $80^{\circ} \mathrm{C}$. After the solution had cooled, its radioactivity was determined (total $\mathrm{Hg}$ ). Then, a sub-sample was added to $8 \mathrm{M}$ urea, mixed, and allowed to stand for $10 \mathrm{~min}$. A total of $2 \mathrm{ml}$ of $0.5 \mathrm{M}$ $\mathrm{CuSO}_{4}$ and $2 \mathrm{ml}$ of concentrated hydrochloric acid were added. This mixture was extracted with toluene, the radioactivity of the aqueous phase was measured (inorganic $\mathrm{Hg}$ ), and the percentage of MeHg calculated. This method ensured a quantitative recovery of $\mathrm{MeHg}(>98 \%$ ) (Rouleau et al. 1992).

Description of 2-and 3-compartment models. Based on the food pathway in the starfish (Jangoux \& Lawrence 1982), 2- and 3-compartment models (Fig. 1) were defined and used to characterize observed distribution kinetics. In the 2-compartment model, Compartment E consists of the mouth, stomach, and rectal caeca while Compartment $\mathrm{CR}$ includes the pyloric caeca and the rest of the individual (gonads, body wall, podia, and coelomic fluid). In the 3-compartment model, the pyloric caeca and the rest of individual constitute 2 separate compartments, named C and $\mathrm{R}$, respectively. Exchanges between compartments are characterized by 4 rate constants; $k_{12}, k_{21}, k_{23}$, and $k_{32}$. Metal loss from the compartments to the outside is characterized by 2 rate constants, $k_{\mathrm{r} c}$ stands for defecation by rectal caeca during digestive process, and $k_{\mathrm{e}}$ stands for excretion with metabolic wastes.

When elaborating mathematical expressions for these models, the following assumptions were made: (1) instantaneous distribution of chemicals entering a
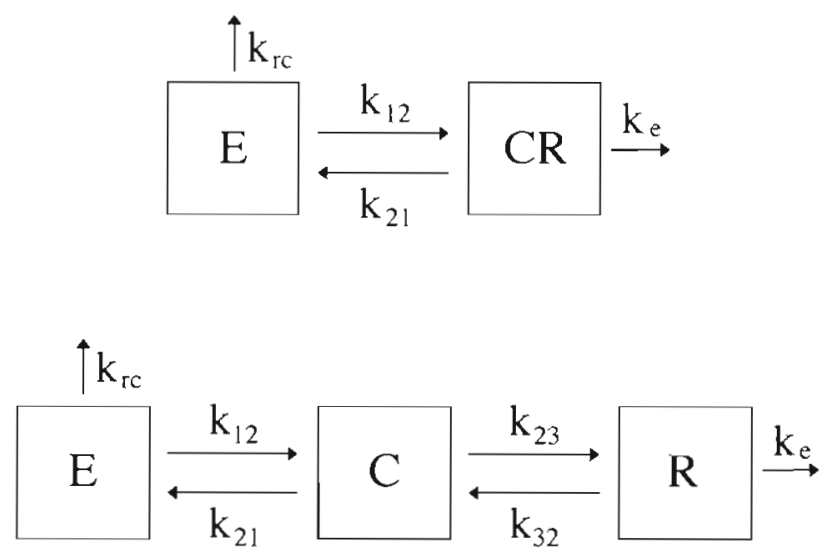

Fig. 1. Leptasterias polaris. 2- and 3-compartment models used in this study. Rate constants $k_{\mathrm{rc}}$ and $k_{e}$ characterize metal loss kinetic with feces (defecation) and metabolic wastes (excretion), respectively, while rate constants $k_{12}, k_{21}, k_{23}$, and $k_{32}$ characterize exchange kinetics of metal species between compartments. E: mouth + stomach + rectal caeca; C: pyloric caeca $_{i} \mathrm{R}$ : rest of individual (gonads, body wall, podia, coelomic fluid); CR: $C+R$ 
compartment to all the tissues forming the compartment; (2) linear distribution of chemicals in every tissue associated with a compartment, with concentrations directly proportional to the amount of chemicals in the whole compartment; (3) first order transfer kinetic of chemicals from a compartment directly proportional to the concentration in the compartment, rate constants being fractional removal rates per unit of time; (4) negligible defecation during the digestive process; (5) no change in speciation of chemicals during the course of the experiment.

The first 3 assumptions are common to most compartmental models (Barron et al. 1990). As the instantaneous distribution was of prime importance in this particular model development, WBARG was used to monitor the digestive process of the starfish and to localize labelled metal species in diffuse and tiny anatomical structures. The fourth assumption is related to the particular physiology of asteroids. Since digestion of food is very complete in asteroids and little feces are defecated (Jangoux \& Lawrence 1982), $k_{\mathrm{rc}}$ was considered as negligible in the present short-time experiments. The fifth hypothesis is an intrinsic condition to these models as no attempt was made to introduce chemicals parameters at the present time.

For the 2-compartment model, if $k_{\mathrm{e}}$ can be considered small relatively to $k_{12}$ and $k_{21}$, expressions for $E$ and $C R$, which represent the quantity of a given metal species at time $t$ in Compartments $E$ and $C R$, respectively, can be written:

$$
\begin{aligned}
E & =\frac{Q_{0}}{k_{12}+k_{21}}\left(k_{21} \mathrm{e}^{-k_{\mathrm{e}} t}+k_{12} \mathrm{e}^{-\beta t}\right) \\
C R & =\frac{k_{12} Q_{0}}{k_{12}+k_{21}}\left(\mathrm{e}^{-k_{\mathrm{e}} t}-\mathrm{e}^{-\beta t}\right)
\end{aligned}
$$

where $Q_{0}$ is the total quantity of the metal species at $t=0$, and $\beta$ is the sum of rate constants $k_{12}, k_{21}$ and $k_{e}$ (Rouleau 1994). Typical curves for this model are presented in Fig. 2A. They show the gradual transfer of the initial quantity of metal $\left(Q_{0}\right)$ from Compartment $E$ to Compartment $C R$. As there is a net loss from the system by excretion, the quantity of metal in compartments will reach zero at $t=\infty$.

However, the quantity of metal species at time $t$ in compartments is directly dependent upon the initial quantity absorbed with food, $Q_{0}$. Due to the variable size of starfish and the use of a constant 'quantity of food/total body weight' ratio, $Q_{0}$ was sometimes quite different from one individual to another, resulting in high variability of calculated kinetics parameters. This problem was circumvented by plotting the proportion of the total body burden of metal contained in each compartment $[E /(E+C R)$ and $C R /(E+C R)]$ versus time. In this way, the total metal content $(E+C R)$ is always equal to 1 and a plateau is reached in both
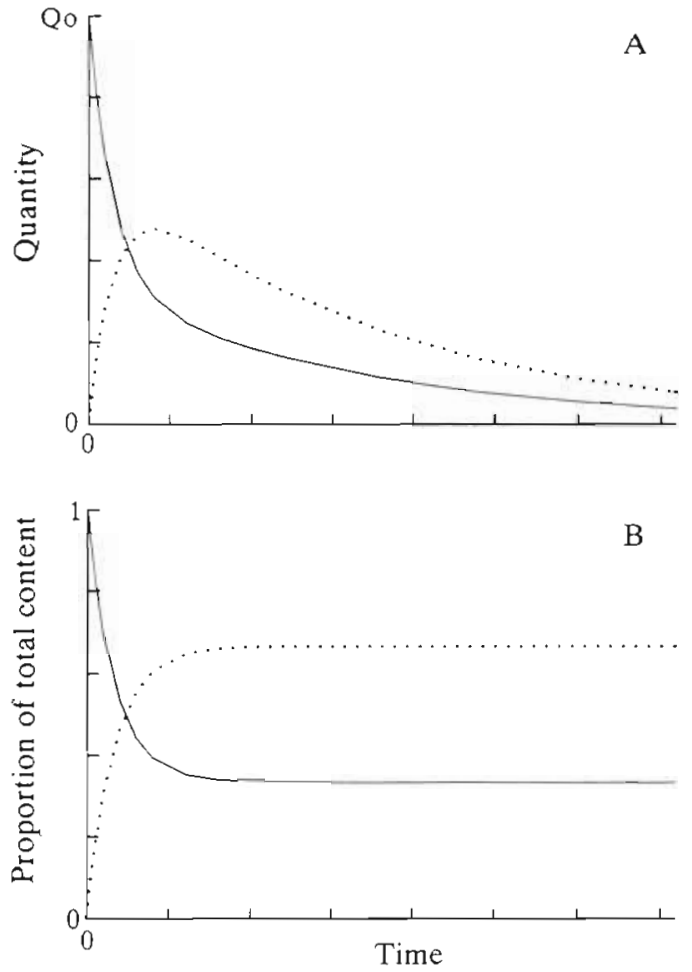

Fig. 2. (A) Typical curves for the variation of the quantity of metal in a 2-compartment model according to Eqs. (4) \& (5). (B) Typical curves for the variation of the proportion of wholebody content of metal in a 2-compartment model. Continuous lines are for Compartment $E$ and dotted lines for Compartment CR

compartments after a given time (Fig. 2B), illustrating the steady-state of the relative distribution despite the continuous loss of metal from the system. It can also be shown that the distribution and time needed to reach its steady-state are independent from $k_{\mathrm{e}}$ (Rouleau 1994). Furthermore, expressing experimental data as a proportion of the whole-body content avoids the need for a reference tissue, the whole-body content being the reference itself.

Such an approach allows us to relate the present model to existing pharmacokinetic compartmental models as the proportion of the whole-body content of Compartments $\mathrm{E}$ and $\mathrm{CR}$ ( $E$ and $C R$ ) can be related to the apparent volume of distribution defined in Eq. (1):

$$
\begin{gathered}
\frac{V_{\mathrm{E}}}{V_{\mathrm{W}}}=\frac{E C_{\mathrm{r}}}{C_{\mathrm{r}} Q}=\frac{E}{Q}=E \\
\frac{V_{\mathrm{CR}}}{V_{\mathrm{W}}}=\frac{C R C_{\mathrm{r}}}{C_{\mathrm{r}} Q}=\frac{C R}{Q}=C R
\end{gathered}
$$

where $V_{\mathrm{E}}, V_{C R}$, and $V_{\mathrm{W}}$ are the apparent volumes of distribution of Compartments $E$ and $C R$, and of the whole animal, respectively. 
The size of $V$ for a given compartment, and thus the proportion of the metal body burden, depend on the animal species, the anatomical volume, and the chemical's partitioning and binding to tissues (Barron et al. 1990). Wet weights of adult starfish compartments were quite variable (Table 1). However, when the proportion of one compartment toward the total body weight was expressed as a percentage of the total weight, the variability was strongly reduced indicating that the relative size of each compartment was quite constant and independent from the whole-body size within the sampled size range. Thus, the distribution of metal species can be considered here as independent from the specimen size. As variations of metabolism can affect the uptake and distribution of trace metals in aquatic organisms (Depledge \& Rainbow 1990), experiments were conducted only on a short-time scale (48 h), under rigorously controlled environmental conditions, and during the same season of the year to minimize any possible metabolic effects.

As metal distribution is independent of $k_{\mathrm{e}}$, both models are reduced to:

$$
\begin{aligned}
& \text { 2-compartment model: } \quad E \underset{k_{21}}{\stackrel{k_{12}}{\rightleftarrows}} C R \\
& \text { 3-compartment model: } \quad E \underset{k_{21}}{\stackrel{k_{12}}{\rightleftarrows}} C \underset{k_{32}}{\stackrel{k_{23}}{\rightleftarrows}} C R
\end{aligned}
$$

For a 2-compartment model, expressions for $\boldsymbol{E}$ and $C R$ can be written:

$$
\begin{aligned}
& \boldsymbol{E}=\boldsymbol{E}_{\mathrm{SS}}\left(1-\mathrm{e}^{-\alpha_{1} t}\right)+\mathrm{e}^{-\alpha_{1} t} \\
& \boldsymbol{C} \boldsymbol{R}=\boldsymbol{C R}_{\mathrm{SS}}\left(1-\mathrm{e}^{-\alpha_{1} t}\right)
\end{aligned}
$$

where $\boldsymbol{E}_{\mathrm{SS}}$ and $\boldsymbol{C} \boldsymbol{R}_{\mathrm{SS}}$ are values of $\boldsymbol{E}$ and $\boldsymbol{C R}$ at steadystate and $\alpha_{1}$ (the sum of $k_{12}$ and $k_{21}$ ) is the rate constant characterizing the rate at which steady-state is achieved. Values of $\boldsymbol{E}_{S S}, \boldsymbol{C R}_{\mathrm{SS}}$, and $\alpha_{1}$ were calculated from experimental data by non-linear least square regression analysis using STATGRAPH ${ }^{\circledR}$. Apparent distribution rate constants $k_{12}$ and $k_{21}$ were then calculated as following:

$$
\begin{gathered}
k_{12}=\boldsymbol{C} \boldsymbol{R}_{\mathrm{SS}} \alpha_{1} \\
k_{21}=\boldsymbol{E}_{\mathrm{SS}} \alpha_{1}
\end{gathered}
$$

To simplify mathematical expressions of $\boldsymbol{E}, \boldsymbol{C}$, and $\boldsymbol{R}$ (the proportion of the whole-body content in these compartments) versus time, the 3-compartment model was considered as a true catenary model in which compartments arranged in a row are connected in series only to their nearest neighbours (DiStefano \& Landaw 1984), which means that exchanges between Compartments $E$ and $\mathrm{R}$ were negligible. Thus, the equation for $\boldsymbol{E}$ already developed for the 2-compartment model (Eq. 8) also holds for the 3-compartment system. The mathematical
Table 1. Leptasterias polaris. Wet weight of starfish compartments and their percentage of total specimen wet weight Values are means $\pm \mathrm{SD}(\mathrm{n}=128)$

\begin{tabular}{|lcc|}
\hline & Wet weight $(\mathrm{g})$ & \% total weight \\
\hline Compartment E & $4.5 \pm 2.1$ & $4.7 \pm 1.0$ \\
Compartment C & $8.6 \pm 4.5$ & $8.9 \pm 2.6$ \\
Compartment R & $82.2 \pm 33.0$ & $86.4 \pm 2.7$ \\
Whole individual & $95.3 \pm 38.6$ & 100.0 \\
\hline
\end{tabular}

expression for $\boldsymbol{R}$ becomes similar to the second compartment of the 2-compartment model (Eq. 9), giving:

$$
\boldsymbol{R}=\boldsymbol{R}_{\mathrm{SS}}\left(1-\mathrm{e}^{-\alpha_{2} t}\right)
$$

where $\alpha_{2}$ is the sum of $k_{23}$ and $k_{32}$. As the total body content is always equal to $1, \boldsymbol{C}=1-\boldsymbol{E}-\boldsymbol{R}$ and the following expression can be derived for $C$ :

$$
\boldsymbol{C}=\boldsymbol{C}_{\mathrm{SS}}\left(1-\mathrm{e}^{-\alpha_{1} t}\right)+\boldsymbol{R}_{\mathrm{SS}}\left(\mathrm{e}^{-\alpha_{2} t}-\mathrm{e}^{-\alpha_{1} t}\right)
$$

Values of $\boldsymbol{E}_{\mathrm{SS}}, \boldsymbol{C}_{\mathrm{SS}}, \boldsymbol{R}_{\mathrm{SS}}, \alpha_{1}$, and $\alpha_{2}$ were again estimated from experimental data, and apparent distribution rate constants were calculated as following:

$$
\begin{aligned}
& k_{12}=\frac{C_{\mathrm{SS}} \alpha_{1}}{E_{\mathrm{SS}}+C_{\mathrm{SS}}} \\
& k_{21}=\frac{E_{\mathrm{SS}} \alpha_{1}}{E_{\mathrm{SS}}+C_{\mathrm{SS}}} \\
& k_{23}=\frac{\boldsymbol{R}_{\mathrm{SS}} \alpha_{2}}{\boldsymbol{R}_{\mathrm{SS}}+C_{\mathrm{SS}}} \\
& k_{32}=\frac{C_{\mathrm{SS}} \alpha_{2}}{R_{\mathrm{SS}}+C_{\mathrm{SS}}}
\end{aligned}
$$

\section{RESULTS}

Experimental data and fitted curves for the 2- and 3-compartment models are presented in Figs. 3 \& 4, respectively. In all cases, experimental data agreed well with regression curves, as $\mathrm{r}^{2}$ values are $\geq 0.7$, except for Compartment $\mathrm{R}$ in the experiment using inorganic $\mathrm{Hg}(\mathrm{II})$ and Compartment $\mathrm{C}$ with $\mathrm{MeHg}$, which exhibit $x^{2}$ below 0.6 (Table 2). A random variation was observed between measured and modelpredicted values, and the sum of squares of deviations was low for all curves (Table 2).

\section{2-compartment model}

Distribution kinetics of inorganic $\mathrm{Hg}(\mathrm{II})$ and $\mathrm{Sn}$ (IV) were almost identical (Fig. 3). The time interval needed to decrease the proportion of metal content in Com- 
Table 2. Values of $r^{2}$ of fitted curves for the 2- and 3-compartment models and sums of squares (SS) of deviations between observed and predicted values, for Compartments $E, C R, C$ and $\mathrm{R}$

\begin{tabular}{|ccccccccc|}
\hline & \multicolumn{4}{c}{$\mathrm{r}^{2}$} & \multicolumn{4}{c}{ SS of deviations } \\
& $\mathrm{E}$ & $\mathrm{CR}$ & $\mathrm{C}$ & $\mathrm{R}$ & $\mathrm{E}$ & $\mathrm{C}$ & $\mathrm{R}$ \\
\hline $\mathrm{Hg}(\mathrm{II})$ & 0.86 & 0.85 & 0.81 & 0.54 & & 0.51 & 0.42 & 0.17 \\
$\mathrm{MeHg}$ & 0.77 & 0.78 & 0.51 & 0.72 & & 0.40 & 0.27 & 0.19 \\
$\mathrm{Sn}(\mathrm{IV})$ & 0.96 & 0.96 & 0.90 & 0.68 & & 0.20 & 0.36 & 0.10 \\
$\mathrm{But}_{3} \mathrm{Sn}$ & 0.92 & 0.97 & 0.90 & 0.75 & & 0.41 & 0.46 & 0.08 \\
& & & & & & & & \\
\hline
\end{tabular}

partment $\mathrm{E}$ by $50 \%$ was approximately $5 \mathrm{~h}$. Steadystate distribution was almost achieved $24 \mathrm{~h}$ after food injection. Values of $\boldsymbol{E}_{\mathrm{SS}}$ and $\boldsymbol{C R}_{\mathrm{SS}}$ (Table 3) were similar, as 87 to $89 \%$ of the inorganic $\mathrm{Hg}$ and $\mathrm{Sn}$ contents were found in the Compartment CR. The value of the rate constant $\alpha_{1}$ was also similar for both metals (Table 3). Values of apparent distribution rate constants $k_{12}$ and $k_{21}$ calculated from Eqs. (10) \& (11) have similar values for both inorganic $\mathrm{Hg}$ and $\mathrm{Sn}$ (Table 4), and the $k_{12} / k_{21}$ ratios were higher than 6 .

Rate of transfer of MeHg was rather similar to inorganic $\mathrm{Hg}$ and $\mathrm{Sn}$, as the value of $\boldsymbol{E}$ decreased by $50 \%$ within $7 \mathrm{~h}$ after food injection and steady-state distribution was reached after $24 \mathrm{~h}$. However, less $\mathrm{MeHg}$ was transferred between compartments; $\boldsymbol{E}_{\mathrm{SS}}$ and $\boldsymbol{C} \boldsymbol{R}_{\mathrm{SS}}$ values were, respectively, 3 times higher and 1.4 times lower than those found for inorganic $\mathrm{Hg}$ and $\mathrm{Sn}$ (Table 3). Rate constant $\alpha_{1}$ had a value similar to those found for inorganic $\mathrm{Hg}$ and $\mathrm{Sn}$. However, $k_{12}$ and $k_{21}$ were, respectively, lower and higher than for both inorganic ions (Table 4 ), resulting in a $k_{12} / k_{21}$ ratio of only 1.7 .
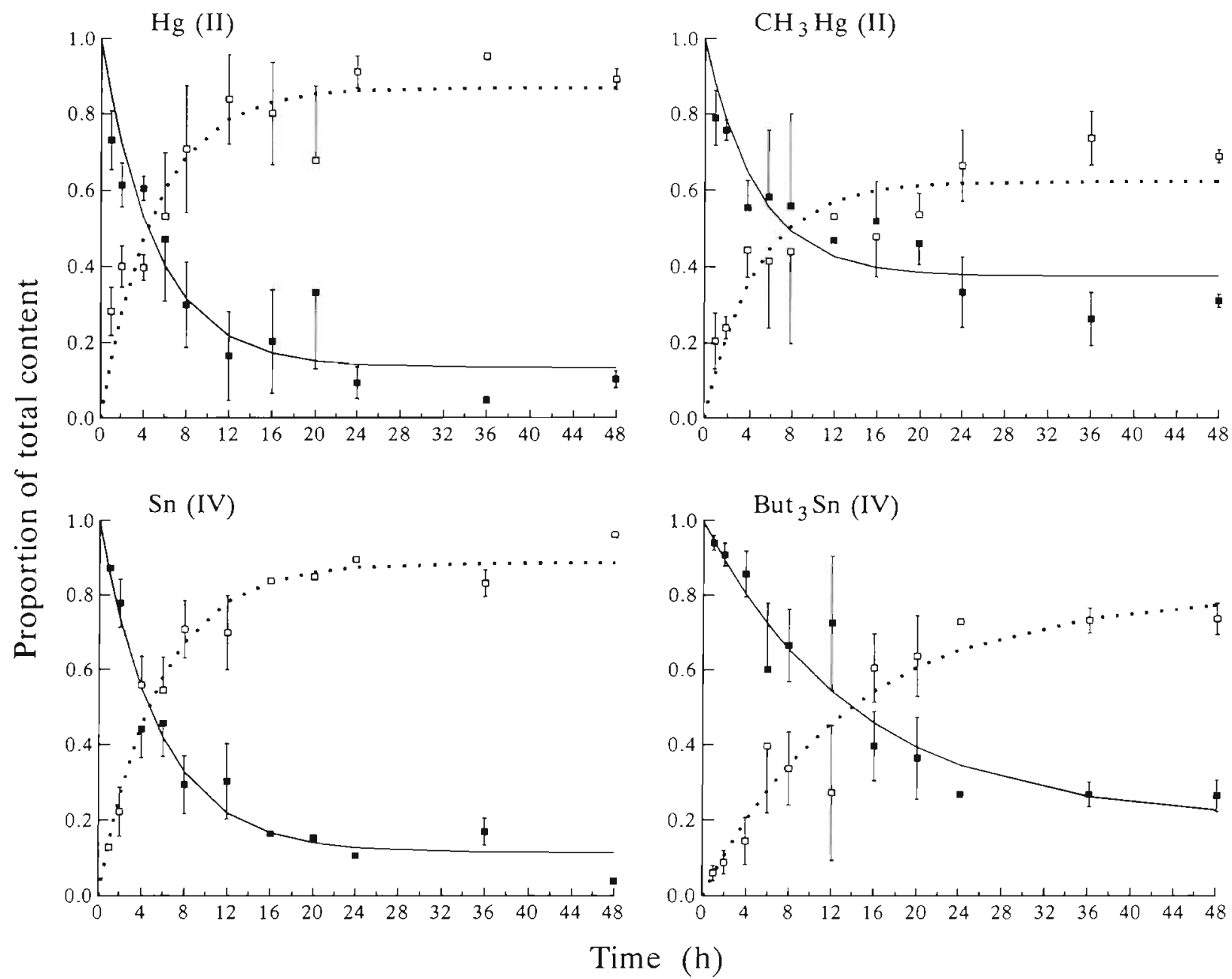

Fig. 3. Leptasterias polaris. Distribution kinetics of MeHg, But 3 Sn, and inorganic $\mathrm{Hg}(\mathrm{II})$ and Sn(IV) in starfish using the 2-compartment model. Data points are means $\pm \mathrm{SD}(\mathrm{n}=3)$. (-) Compartment E (mouth, stomach, and rectal caeca); $(0 . .$. ㅁ) Compartment CR (pyloric caeca and the rest of individual). Fitted curves were obtained by non-linear regression analysis using Eqs. (8) \& (9) 
Table 3. Leptasterias polaris. Values ( \pm SE) of distribution parameters and transfer rate constants calculated from experimental data by non-linear regression analysis for the 2 - and 3-compartment models

\begin{tabular}{|ccccccc|}
\hline & $\boldsymbol{E}_{\mathrm{SS}}$ & $\boldsymbol{C} \boldsymbol{R}_{\mathrm{SS}}$ & $\boldsymbol{C}_{\mathrm{SS}}$ & $\boldsymbol{R}_{\mathrm{SS}}$ & $\boldsymbol{\alpha}_{1}$ & $\boldsymbol{\alpha}_{2}$ \\
\hline $\mathrm{Hg}(\mathrm{II})$ & $0.134 \pm 0.034$ & $0.869 \pm 0.034$ & $0.608 \pm 0.030$ & $0.260 \pm 0.027$ & $0.196 \pm 0.028$ & $0.061 \pm 0.015$ \\
$\mathrm{MeHg}$ & $0.375 \pm 0.030$ & $0.622 \pm 0.030$ & $0.311 \pm 0.024$ & $0.319 \pm 0.024$ & $0.208 \pm 0.037$ & $0.099 \pm 0.020$ \\
Sn(IV) & $0.114 \pm 0.022$ & $0.886 \pm 0.022$ & $0.626 \pm 0.026$ & $0.259 \pm 0.013$ & $0.178 \pm 0.015$ & $0.413 \pm 0.103$ \\
But ${ }_{3}$ Sn & $0.200 \pm 0.039$ & $0.799 \pm 0.039$ & $0.419 \pm 0.042$ & $0.368 \pm 0.038$ & $0.071 \pm 0.008$ & $0.017 \pm 0.002$ \\
\hline
\end{tabular}

The most striking feature of But 3 Sn distribution kinetic was its slowness. The value of $E$ was reduced by $50 \%$ after only $14 \mathrm{~h}$, and the regression curve did not reach a plateau during the course of our experiment. Rate constant $\alpha_{1}$ exhibited a value 2.5 to 3 times lower than for the other metal species. Values of $E_{S S}$ and $C_{S S}$ fell between those of $\mathrm{MeHg}$ and the inorganic ions. Apparent distribution rate constants $k_{12}$ and $k_{21}$ were also the lowest observed, and the ratio of rate constants, $k_{12} / k_{21}$, reached 4 .

\section{3-compartment model}

Quite similar regression curves were recorded for inorganic $\mathrm{Hg}(\mathrm{II})$ and Sn(IV) although Sn(IV) in Compartment $C$ reached a plateau much earlier $(t \approx 10 \mathrm{~h}$ ) than $\mathrm{Hg}(\mathrm{II})$ (Fig. 4). A maximum, slightly higher than the final value, was observed in Compartment $C$ of both inorganic $\mathrm{Hg}(\mathrm{II})$ and $\mathrm{MeHg} . \boldsymbol{C}_{\mathrm{SS}}$ and $\boldsymbol{R}_{\mathrm{SS}}$ values (Table 3) showed that 61 to $63 \%$ of inorganic $\mathrm{Hg}(\mathrm{II})$ and Sn(IV) were found in Compartment $\mathrm{C}$ at steadystate while $26 \%$ of the metal content was present in Compartment $\mathrm{R}$. Although the values of rate constants characterizing the transfer between Compartments $C$ and $\mathrm{R}$ were lower for inorganic $\mathrm{Hg}$ than inorganic $\mathrm{Sn}$ $\left(\alpha_{2}, k_{23}\right.$, and $k_{32}$; Tables $\left.3 \& 4\right)$, both $k_{23} / k_{32}$ ratios were equal to 0.4 (Table 4). As expected from model equations, values for $k_{12}$ and $k_{21}$ calculated by the 2compartment model were different from those calculated from the 3-compartment model (Table 4).

$\mathrm{MeHg}$ was remarkable by its even distribution between compartments at steady-state; values of $\boldsymbol{E}_{\mathrm{SS}}$, $C_{S S}$ and $R_{S S}$ were all within the range 0.31 to 0.38
(Table 3). The value of $\alpha_{2}$ was $60 \%$ higher than the corresponding value for inorganic $\mathrm{Hg}$. Values calculated for $k_{12}$ and $k_{21}$ were rather different from those found for the 2-compartment model leading to a $k_{12} / k_{21}$ ratio of 0.8 . Rate constants $k_{23}$ and $k_{32}$ were similar (Table 4 ), resulting in a $k_{23} / k_{32}$ ratio of 1 .

The slow rate of transfer of $\mathrm{But}_{3} \mathrm{Sn}$ between compartments was evidenced by the 3-compartment model. Steady-state distribution was not achieved after $48 \mathrm{~h}$ as predicted values of $\boldsymbol{E}, \boldsymbol{C}$ and $\boldsymbol{R}$ at that time $(0.24,0.52$, and 0.24 , respectively) were different from those of $E_{\mathrm{SS}}$ $\boldsymbol{C}_{\mathrm{SS}}$ and $\boldsymbol{R}_{\mathrm{SS}}$ (Table 3 ). The value of $\alpha_{2}$ for But ${ }_{3} \mathrm{Sn}$ was the lowest observed. Rate constants $k_{23}$ and $k_{32}$ were almost equal (Table 4 ), and the $k_{23} / k_{32}$ ratio was close to 1 , as observed for MeHg. Ratios $k_{12} / k_{21}$ calculated from 2-and 3-compartment models differed by 2 units.

The distribution of metal species in organs and tissues forming the Compartment $\mathrm{R}$, expressed as their percent contribution to the total metal content in $\mathrm{R}$, was examined in detail (Fig. 5). Average values ( \pm SD) for each metal and each tissues are given in Table 5 . No clear trend as a function of sampling times can be observed for any tissues or metal species. The contribution of some organs was sometimes highly variable in the first few hours ( $1 \mathrm{~h}, 2 \mathrm{~h}, 4 \mathrm{~h})$ of experiments, but individual values tended toward average values as elapsed time increased. This almost constant distribution of metal species within Compartment $\mathrm{R}$ indicated that these tissues actually constituted a kinetically homogenous unit, according to the assumption of linear distribution. The inorganic Sn content of the coelomic fluid was much higher relative to the other metal species (Table 5).

Table 4. Leptasterias polaris. Values of 4 apparent distribution rate constants $\left(k_{12}, k_{21}, k_{23}\right.$, and $\left.k_{32}, h^{-1}\right)$ calculated from $E_{\mathrm{SS}} \boldsymbol{C} \boldsymbol{R}_{\mathrm{SS}}$ $C_{\mathrm{SS}}, \boldsymbol{R}_{\mathrm{SS}}, \alpha_{1}$, and $\alpha_{2}$ for the 2 - and 3-compartment models

\begin{tabular}{|cccccccccc|}
\hline & \multicolumn{3}{c}{2 -compartment model } & \multicolumn{3}{c}{3 -compartment model } \\
& $k_{12}$ & $k_{21}$ & $k_{12} / k_{21}$ & $k_{12}$ & $k_{21}$ & $k_{12} / k_{21}$ & $k_{23}$ & $k_{32}$ & $k_{23} / k_{32}$ \\
\hline $\mathrm{Hg}(\mathrm{lI})$ & 0.170 & 0.026 & 6.5 & 0.160 & 0.036 & 4.4 & 0.018 & 0.043 \\
$\mathrm{MeHg}$ & 0.130 & 0.078 & 1.7 & 0.094 & 0.114 & 0.8 & 0.050 & 0.049 \\
$\mathrm{Sn}(\mathrm{IV})$ & 0.158 & 0.020 & 7.9 & 0.151 & 0.027 & 5.6 & 0.121 & 0.292 & 0.4 \\
$\mathrm{But}_{3} \mathrm{Sn}$ & 0.057 & 0.014 & 4.1 & 0.048 & 0.023 & 2.1 & 0.008 & 0.009 & 0.9 \\
\hline
\end{tabular}


$\mathrm{E}$
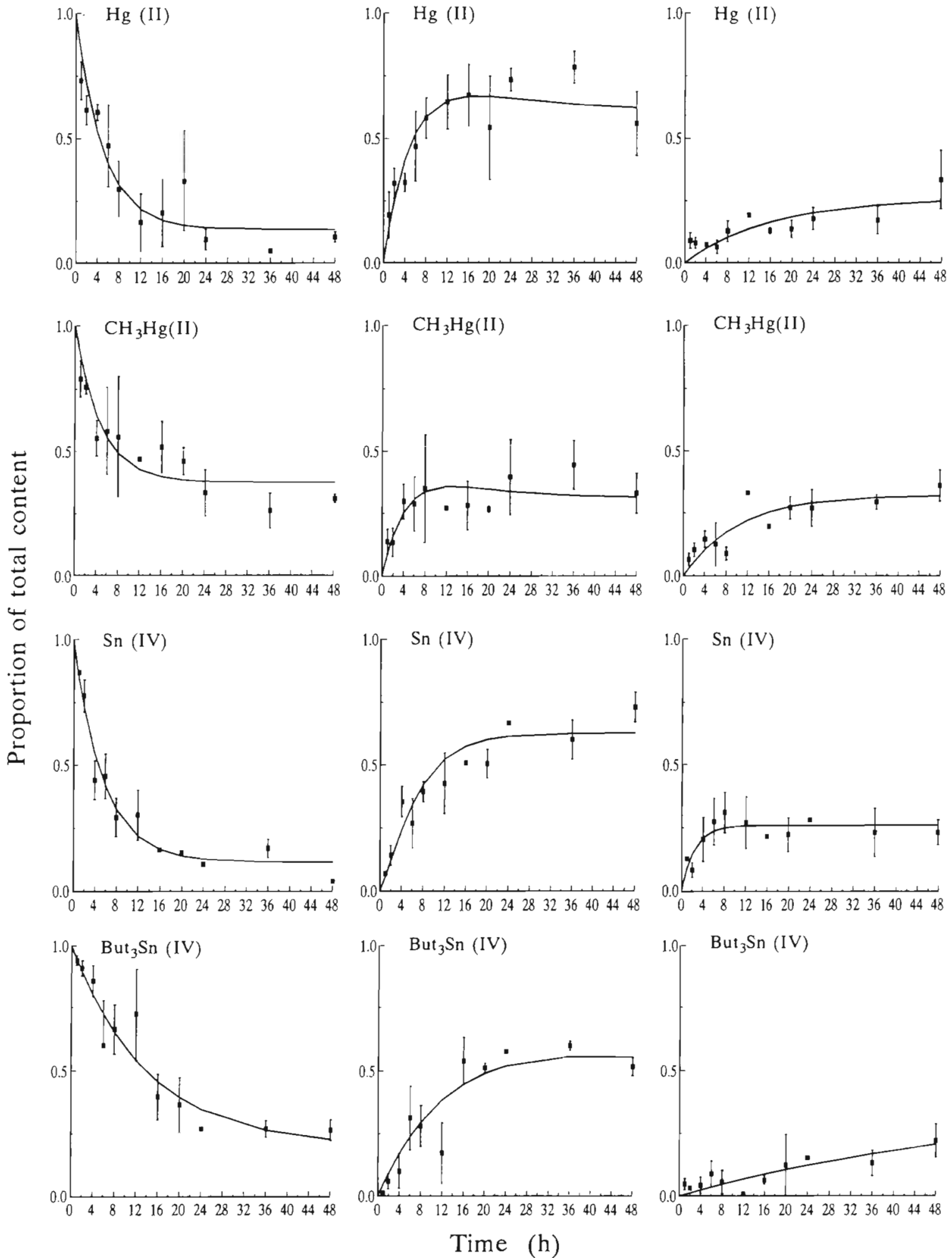

Fig. 4. Leptasterias polaris. Distribution kinetics of $\mathrm{MeHg}_{3} \mathrm{But}_{3} \mathrm{Sn}$, and inorganic $\mathrm{Hg}(\mathrm{II})$ and $\mathrm{Sn}(\mathrm{IV}$ ) in starfish using the 3-compartment model. Data points are means $\pm \mathrm{SD}(\mathrm{n}=3)$. Fitted curves were obtained from non-linear regression analysis with Eqs. (8), (12) \& (13). Compartment E consists of mouth, stomach, and rectal caeca, Compartment C of pyloric caeca, and Compartment $\mathrm{R}$ of the rest of the individual (coelomic fluid, gonads, body wall, podia) 

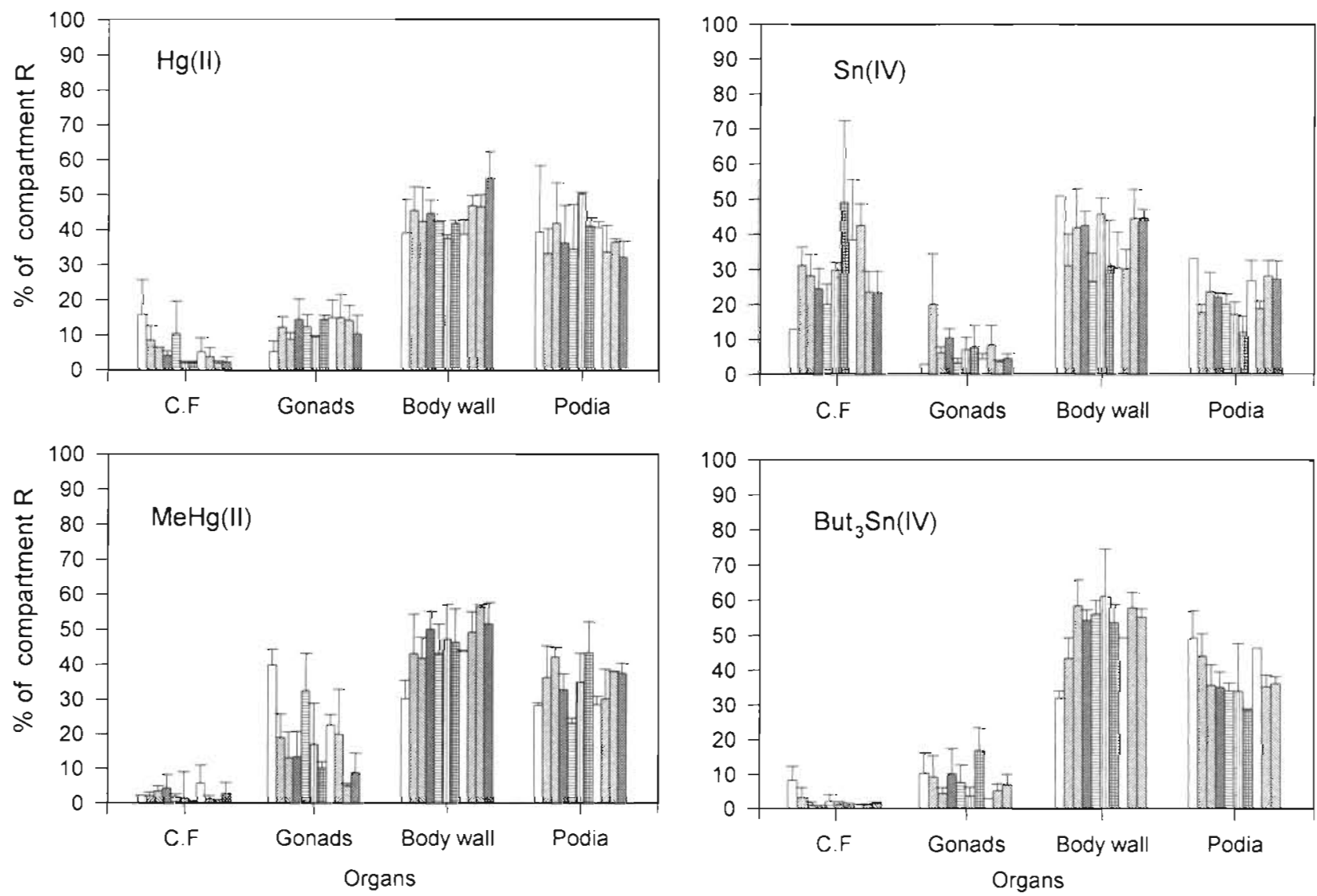

Fig. 5. Leptasterias polaris. Distribution of metal species in organs and tissues forming Compartment R. Each bar represents the percentage of total metal in $\mathrm{R}$ (mean $\% \pm \mathrm{SD}, \mathrm{n}=3$ ) for a given sampling interval. Each group of bars contains all the sampling intervals for a given tissue (from left to right: $1,2,4,6,8,12,16,20,24,36$, and 48 h). C.F.: coelomic fluid

\section{Whole-body autoradiography}

Autoradiograms of starfish fed with labelled food are shown in Figs. $6 \&$ 7. Food content of the stomach accounted for most of its labelling in starfish sampled $6 \mathrm{~h}$ after injection of food, while pictures at 16 and $48 \mathrm{~h}$ show that labelling of this organ resulted mostly from radioactive isotopes incorporated in the tissues. The intense labelling of the pyloric ducts, particularly visible in Figs, $6 \mathrm{~A}, 6 \mathrm{~F} \& 7 \mathrm{~F}$, confirmed that transport

Table 5. Leptasterias polaris. Average percent contribution of organs and tissues to the total metal content of Compartment

$\mathrm{R}$. Values are means $\pm \mathrm{SD}$ of all sampling intervals

\begin{tabular}{|lrccc|}
\hline \multicolumn{5}{c|}{$\%$ of Compartment R content } \\
& Coelomic fluid & Gonads & Body wall & Podia \\
\hline $\mathrm{Hg}(\mathrm{II})$ & $6.0 \pm 6.5$ & $12.1 \pm 5.2$ & $44.1 \pm 7.4$ & $37.1 \pm 10.4$ \\
$\mathrm{MeHg}$ & $3.8 \pm 7.7$ & $17.0 \pm 11.8$ & $45.0 \pm 9.9$ & $34.3 \pm 8.3$ \\
$\mathrm{Sn}(\mathrm{IV})$ & $25.5 \pm 6.9$ & $7.8 \pm 7.4$ & $43.5 \pm 9.5$ & $23.1 \pm 6.1$ \\
$\mathrm{But}_{3} \mathrm{Sn}$ & $2.4 \pm 2.8$ & $8.4 \pm 5.9$ & $52.1 \pm 10.0$ & $37.1 \pm 8.3$ \\
& & & & \\
\hline
\end{tabular}

of metal species from the stomach to the pyloric caeca occurred mainly by this route. No labelling of tissues surrounding the stomach was visible, indicating the probable low direct diffusion from the stomach to the internal cavity. The rectal caeca were rather difficult to observe because they are small and often mingle with stomach tissues. The highly labelled structures in the stomach region in Fig. $6 \mathrm{~B}$ may be related to rectal caeca, although it was not possible to undoubtedly identify them on this radial section. An autoradiogram showing a good picture of the rectal caeca was obtained from a starfish sampled after $16 \mathrm{~h}$ (Fig. 7B). An enlargement of this autoradiogram (Fig. 8) showed a more intense labelling of the rectal caecum wall compared to the lumen, which may be indicative of the absorption of the metal transported in this organ.

Pyloric caeca were highly labelled for all metal species at all sampling times, and labelling was uniformly distributed along these organs indicating that isotopes transported from stomach to pyloric caeca were rapidly distributed in the whole tissue mass of the latter. However, it should be mentioned that it was not 
$\mathrm{Hg}$ (II)

PYLORIC DUCT
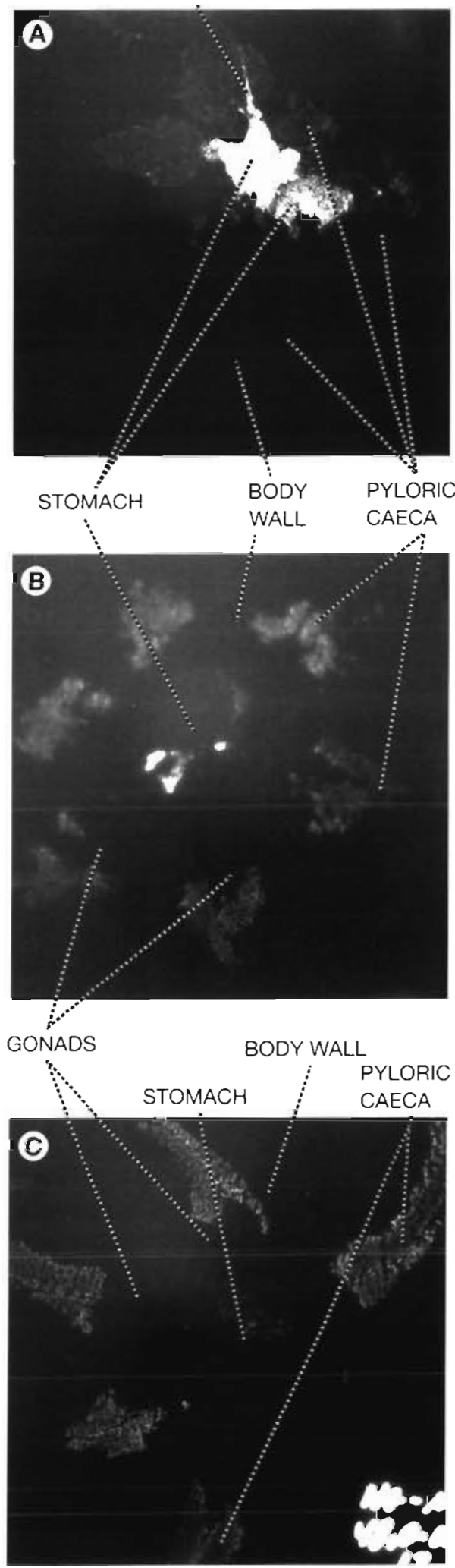

$\mathbf{t}$
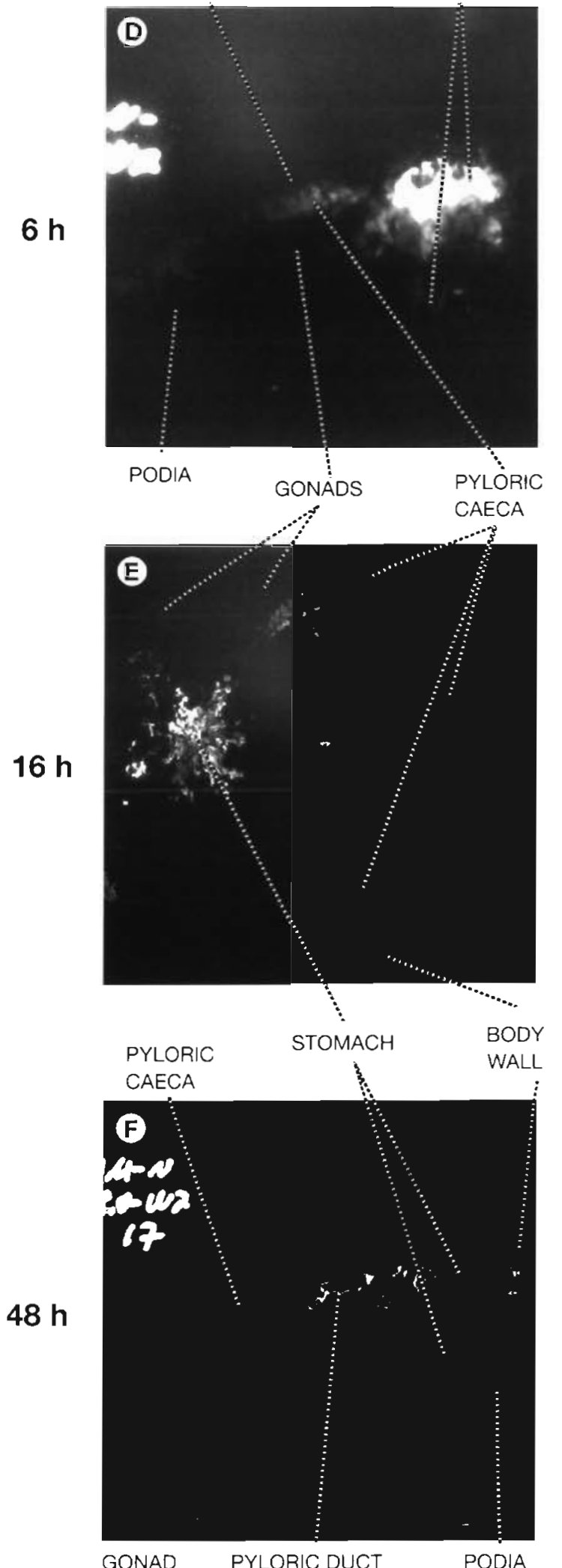

Fig. 6. Leptasterias polaris. Whole-body autoradiograms of starfish 6,16 , and $48 \mathrm{~h}$ after injection of food contaminated with inorganic $\mathrm{Hg}(\mathrm{II})$ and $\mathrm{MeHg}$. (A), (B). (C), and (E) are from whole-body sections in the radial plane. (D) and (F) are from whole-body sections in the transversal plane 


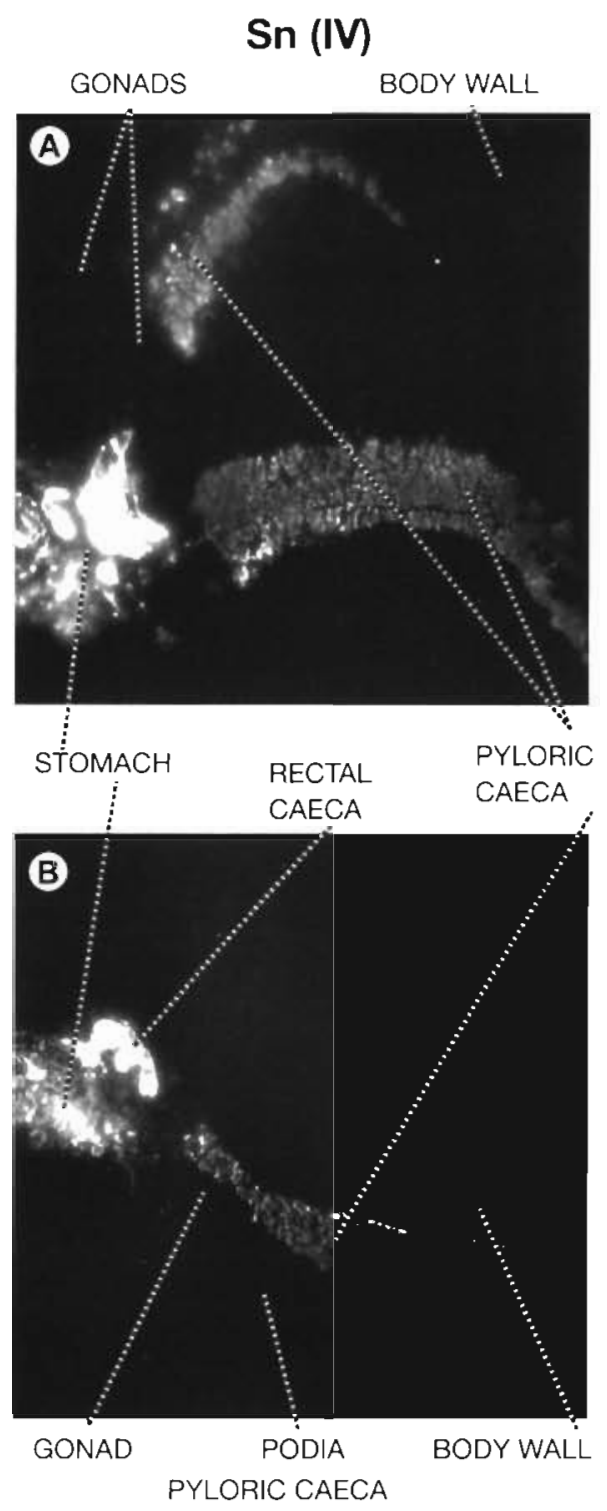

t

\section{But $_{3}$ Sn (IV)}

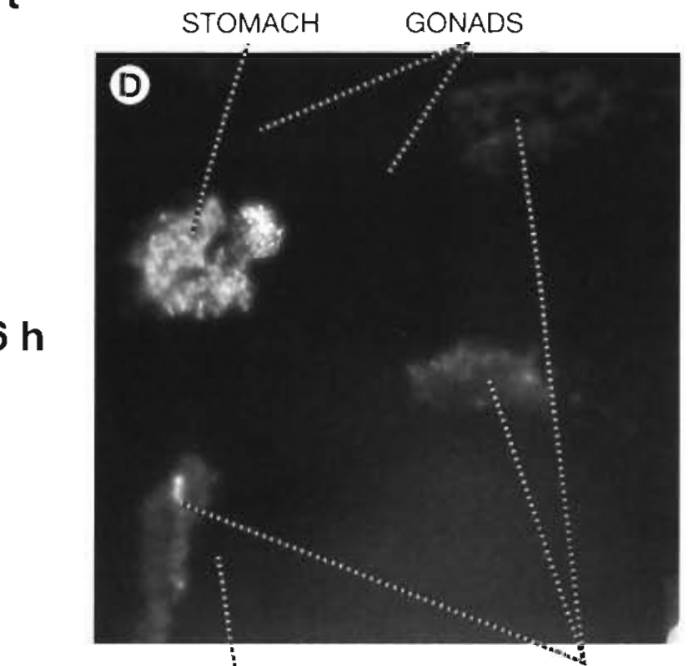

BODY WALL

PYLORIC CAECA
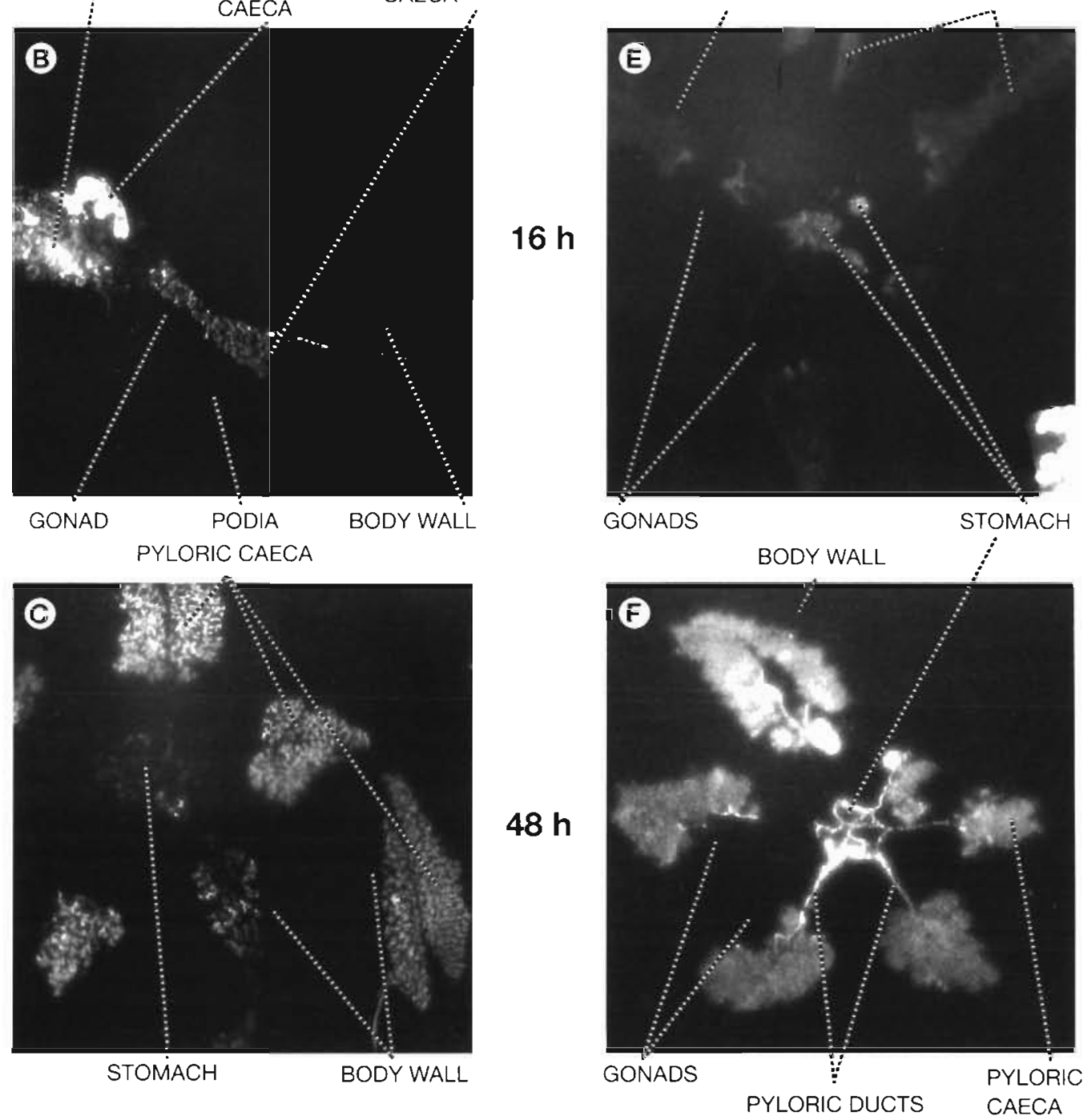

Fig. 7 Leptasterias polaris. Whole-body autoradiograms of starfish 6,16 , and $48 \mathrm{~h}$ after injection of food contaminated with inorganic $\mathrm{Sn}(\mathrm{IV})$ and $B \mathrm{t}_{3} \mathrm{Sn}$. (A), (C), (D), (E), and (F) are from whole-body sections in the radial plane. (B) is from a whole-body section in the transversal plane 


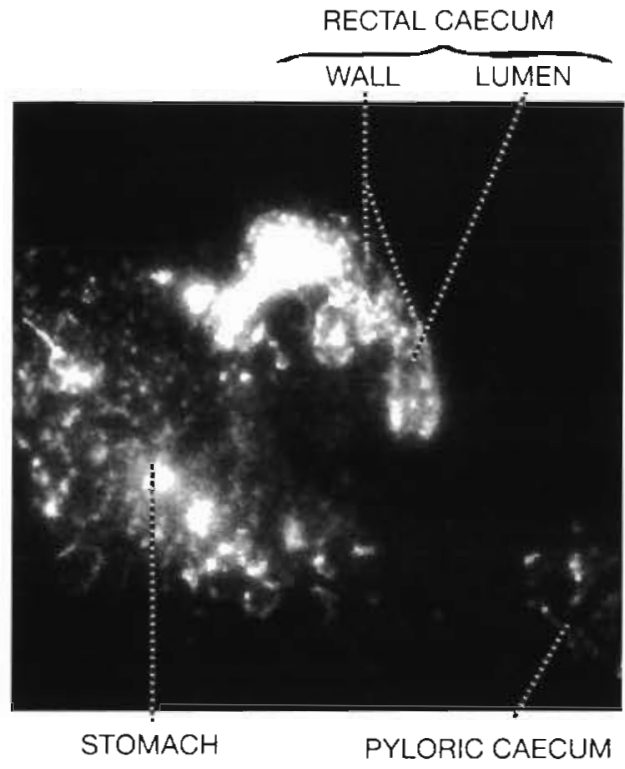

Fig. 8. Leptasterias polaris. Enlargement of Fig. 7B showing stomach and rectal caecum labelling in a starfish fed with inorganic Sn(IV)-contaminated food

possible to make a distinction between extracellular isotopes and isotopes absorbed within tissues. The labelling of gonads, body wall, and podia was very low, even $48 \mathrm{~h}$ after the injection of food, when approximately $30 \%$ of the isotopes administered were localized in Compartment $\mathrm{R}$ (Table 3). However, isotopes were distributed in a compartment representing more than $85 \%$ of the total wet weight (Table 1), and the dilution effect was responsible for such a low labelling. No evidence was found for the labelling of the haemal system in any autoradiograms examined. Furthermore, radioactivity of individual axial glands was below the detection limit most of the time.

Finally, it is noteworthy that $\mathrm{Hg}$ species determined by selective extraction in the pyloric caeca of starfish injected with $\mathrm{MeHg}$-contaminated food showed that $\mathrm{MeHg}$ accounted for 98 to $100 \%$ of total $\mathrm{Hg}$ in these organs (mean $\pm \mathrm{SD}=99.1 \pm 0.8 \%, \mathrm{n}=6$ ).

\section{DISCUSSION}

\section{Model validation}

Both 2- and 3-compartment models were used to describe kinetics of exchange of tin and mercury species between organs and tissues of a marine invertebrate (Leptasterias polaris). Kinetic parameters were calculated from a series of 4 experiments using as many as 33 starfish for each of them. To our knowledge, this study represents the first attempt to quan- tify and compare the exchange rates of some organometallic species between biological compartments in invertebrates. As mentioned in the description of the models, 5 assumptions concerning the distribution mode, kinetics, metal loss, and chemical speciation were made. Both hypothesis about instantaneous and linear distribution were clearly confirmed by the constant distribution of metal in Compartment $\mathrm{R}$, and by autoradiograms showing homogeneous labelling of pyloric caeca a few hours after contamination, indicating that chemicals entering the starfish via the stomach were distributed very rapidly and linearly within each studied compartment. The low and negligible excretion of mercury species by starfish within a 24 h exposure period was first observed in a study conducted by Maheu \& Pelletier (1994) on excretion rates of inorganic ${ }^{203} \mathrm{Hg}$ (II) and $\mathrm{CH}_{3}{ }^{203} \mathrm{Hg}$ (II) taken from contaminated food. Less than $10 \%$ of ingested labelled mercury was found in surrounding seawater after $24 \mathrm{~h}$. In the present series of experiments, no feces or particulate suspended matter were observed and the high labelling of the rectal caecal walls is indicative of the high absorption capacity of these organs; labelled compounds were thus retained within Compartment $E$. Values of $\mathrm{r}^{2}$ of fitted curves for both compartmental models and sums of squares of deviations between observed and predicted values provide a clear quantitative indication of the validity of the approach used to model experimental results. In addition, estimated kinetic parameters have relatively low standard errors (Table 3), and their values are realistic and consistent, as the sum of $\boldsymbol{E}_{S \mathrm{~S}}+\boldsymbol{C}_{\mathrm{SS}}+\boldsymbol{R}_{\mathrm{SS}}$ (assumed to be equal to 1 ) actually ranged from 0.99 to 1.01 , supporting strongly the third assumption about first-order kinetics.

Methylation of inorganic $\mathrm{Hg}(\mathrm{II})$ is a slow bacterial process which is not likely to have occurred in starfish tissues during this short-term experiment. Furthermore, measurements of $\% \mathrm{MeHg}$ undoubtedly showed that demethylation of $\mathrm{MeHg}$ did not occur in the pyloric caeca. A previous study on the trophic accumulation of But $3 \mathrm{Sn}$ in Leptasterias polaris showed that a small percentage of the product undergoes debutylation only $11 \mathrm{~d}$ after the beginning of contamination (Mercier et al. 1994). The fifth assumption of the model may have been violated in the case of inorganic tin, as its speciation appeared to have been changed during the course of this experiment. $\mathrm{SnCl}_{4}$ is stable at high chloride concentrations $\left(\left[\mathrm{Cl}^{-}\right]>0.9 \mathrm{M}\right)$ as the hexachlorostannate anion. At lower chloride concentrations, $\mathrm{SnCl}_{6}{ }^{2-}$ is rapidly hydrolysed to various forms of hydrated tin(IV) oxides, producing very insoluble and unreactive species (Pascal 1963). As the salinity of seawater used was $26 \%$ (i.e. $\left[\mathrm{Cl}^{-}\right] \approx 0.45 \mathrm{M}$ ) and the fluid filling the starfish internal cavity is isosmotic with seawater, partial or even complete hydrolysis of ${ }^{1.13} \mathrm{SnCl}_{4}$ 
added to food may have occurred during the digestive process. Thus, distribution kinetics of Sn(IV) reported in this work might not be representative of $\mathrm{SnCl}_{4}$ but rather of a mixture of species including hydrolysed forms of Sn(IV) and should be interpreted cautiously.

\section{Interpretation of kinetic data}

As model assumptions appear to be valid within the limits of our present knowledge and curve fitting provided satisfactory results, distribution kinetics can be compared and interpreted in a quantitative way keeping in mind the restrictions mentioned above for inorganic tin species.

The transfer of metal species between compartments results from many steps involving both intra- and intercompartmental processes. The overall rate of such a multi-step phenomenon, i.e. the time needed to proceed from initial to final conditions, is controlled by its slowest step. In present models, the rate at which steady-state is achieved between compartments is related to the rate constants $\alpha_{1}$ and $\alpha_{2}$, which are equal to $\left(k_{12}+k_{21}\right)$ and $\left(k_{23}+k_{32}\right)$, respectively, while the distribution is related to the value of the ratio of individual rate constants. This means that the time needed to reach a steady state is independent of the distribution of the metal. Thus, the transfer of 2 given compounds, $x$ and $y$, may reach steady-state in the same period of time $\left(\alpha_{1 x}=\alpha_{1 y}\right.$ or $\left.k_{12 x}+k_{21 x}=k_{12 y}+k_{21 y}\right)$ even if their distribution is different $\left(k_{12 x} / k_{21 x} \neq k_{12 y} / k_{21 y}\right)$. Values measured for $\alpha_{1}$ and $\alpha_{2}$ are first introduced and distributions are discussed thereafter.

The rate at which steady-state is reached for the transfer of metal species from Compartment $\mathrm{E}$ to Compartment $C$ is characterized by the rate constant $\alpha_{1}$, the driving force being the inward current produced by cells of the stomachal walls. The rate constant $\alpha_{2}$ characterizes the rate at which steady-state is reached for the transfer of metal species from Compartment $\mathrm{C}$ toward Compartment $\mathrm{R}$, a process involving cellular translocations. Muscular movements and other forces maintain well-mixed conditions within the coelomic fluid (Ferguson 1982). Assuming that metal species adsorbed on tissue surfaces exposed to coelomic fluid and within the coelomic fluid are at equilibrium at any time and that absorption and distribution of digestive products occur at approximately the same rate in each exposed group, the translocation of metal species from the tissular mass of the pyloric caeca toward the coelom is likely the key process of the transfer between these 2 compartments. Such a translocation involves passage across the biological barrier formed by pyloric caecal diverticulea thin walls, which are made up of an internal digestive epithelium and an external cuboidal mesothelium separated by a very thin connective layer (Jangoux \& Lawrence 1982). Contributions from other possible routes of translocation are probably negligible, as autoradiograms showed no labelling of structures such as the haemal system.

As both organometallic and inorganic metal species were submitted to the same driving force when moving from Compartment $E$ to $C$, values of $\alpha_{1}$ should be similar and related to the transfer rate of food if this process is the slowest and, thus, the determining step. We found that $\alpha_{1}$ had similar values for MeHg and inorganic $\mathrm{Hg}$ and $\mathrm{Sn}$. The transfer rate of food has not been measured directly, but visual inspection showed that few food particles remained in the stomach 12 and $16 \mathrm{~h}$ after the initial ingestion of food, and usually none after $24 \mathrm{~h}$ for the 4 treatment groups. When time needed to achieve $95 \%$ of the distribution steady-state was calculated $\left(t_{095}=-(\ln 0.05) / \alpha_{1}\right)$, values of $t_{0.95}$ found for $\mathrm{MeHg}$ and inorganic $\mathrm{Hg}$ and $\mathrm{Sn}$ ranged from 14.4 to $16.8 \mathrm{~h}$. As their transfer rates are almost the same in spite of their very different structure and chemical properties, their transport mode toward pyloric caeca was assumed to be mainly passive and associated with that of food.

Surprisingly, the transfer rate of But $3 \mathrm{Sn}$ from the stomach to pyloric caeca was slower than $\mathrm{MeHg}$, indicating that food transfer was apparently not the ratelimiting process. Interactions of organotins with biological systems have been investigated by Musmeci et al. (1992), who observed that at physiological pH in aqueous phase trialkyltin compounds reacted with thiol groups of erythrocytes, haemoglobin, and DNA forming Sn-S bonds. Tin atoms further formed coordination bonds with electron donors present in the vicinity of the Sn-S binding. This particular affinity for thiol groups is also a well-established chemical property of $\mathrm{MeHg}$, but it does not form coordination bonds with electron donors (in the absence of an empty sp orbital) (Carty \& Malone 1979). Furthermore, MeHg is rather soluble in seawater (octanol/water partition coefficient $K_{\text {ow }}=1.7 \pm 0.2$ ) (Major \& Rosenblatt 1991) whereas But ${ }_{3} \mathrm{Sn}$ exhibits a quite low seawater solubility $\left(K_{\mathrm{ow}}=\right.$ 5000 to 6300) (Laughlin et al. 1986b). It is likely that But $_{3} \mathrm{Sn}$ desorbing from food during the digestive process readily bound to the biological components of the stomach walls from where its removal was limited by its particular binding mode and its low solubility in seawater, thus resulting in a much slower translocation rate when compared to $\mathrm{MeHg}$.

If crossing epithelia was the key step of metal species translocation from Compartment $\mathrm{C}$ to $\mathrm{R}$, their ease of permeation should have been reflected in their kinetic results. Permeation mechanisms of inorganic metal ions are relatively well established (Simkiss \& Taylor 1989) whereas organometallic ions have re- 
ceived much less attention. The general model proposed for trialkyltin cations $\left(\mathrm{R}_{3} \mathrm{Sn}^{+}\right)$suggests that they cross membranes as neutral species once bound with an aqueous anion (Bjerrum 1983). In the case of $\mathrm{Hg}$ compounds, rapid diffusion of neutral species $\left(\mathrm{HgCl}_{2}\right.$, $\mathrm{CH}_{3} \mathrm{HgCl}$ ) seems to be the primary transport process (Rothstein 1981, Bienvenue et al. 1984). The value of $\alpha_{2}$ seems to be directly related to the speciation of mercury compounds, as $\mathrm{MeHg}$ is almost completely found as the neutral methylmercury chloride species in seawater and the $\alpha_{2}$ value was higher for $\mathrm{MeHg}$ than for inorganic $\mathrm{Hg}$, which is mainly present in the form of $\mathrm{HgCl}_{3}{ }^{-}$and $\mathrm{HgCl}_{4}{ }^{2-}$ anions (Shin \& Krenkel 1976). Although the mixture of tributyltin species in seawater is dominated by neutral chloride and hydroxide species together with a hydrated complex $\left(\mathrm{But}_{3} \mathrm{SnOH}_{2}{ }^{+}\right)$ and carbonated species (Laughlin et al. 1986b), the $\alpha_{2}$ value of $\mathrm{But}_{3} \mathrm{Sn}$ was the lowest one. As indicated for the transfer rate between Compartments $E$ and $C_{\text {, }}$ its strong binding to cell components, its lipophilicity, or its sterical hindrance (Barron 1990) may render the transfer of this compound to extra- and intracellular aqueous phases more difficult, resulting in a slower translocation rate between Compartments $\mathrm{C}$ and $\mathrm{R}$.

The value of $\alpha_{2}$ for inorganic Sn(IV) was unexpectedly high. It may indicate a really fast transfer from Compartment $\mathrm{C}$ to $\mathrm{R}$, but this result seems better explained by a speciation change of $\mathrm{Sn}(\mathrm{IV})$ due to hydrolysis. High tin content found in the coelomic fluid (Table 5) indicates that inorganic Sn reaching the coelomic fluid was not efficiently transferred to the surrounding tissues. As the coelomic fluid is part of the Compartment $R$, the high value of $\alpha_{2}$ seems to be a bias of the model and is probably due to an interruption of the transfer of Sn(IV) arising from the transformation of chlorotin(IV) species to 'hydrolysed-unexchangeable' tin(IV) species.

A striking feature of these results is the even steadystate distribution of organometals between compartments compared to their corresponding inorganic ions, resulting in a ratio of apparent individual rate constants tending toward unity (Table 4). Among other factors, the metal partitioning between compartments at the steady state depends thermodynamically upon the properties of the tissues which constitute the compartments (like the quantity and the quality of available binding sites and the lipid content) and upon the chemical and physical properties of metal species (like the affinity for specific binding sites and the water/ lipid partitioning). The similarity of the distribution of $\mathrm{MeHg}$ and $\mathrm{But}_{3} \mathrm{Sn}$ might be explained by some similarities of their chemical and/or physical properties. For example, both compounds bind primarily to $\mathrm{SH}$ groups of living tissues. It is also known that $\mathrm{MeHg}$ is quickly transferred from one thiol group to another
(Rabenstein et al. 1983), a chemical property explaining its lability in living organisms compared to inorganic $\mathrm{Hg}(\mathrm{II})$. Both MeHg and But $\mathrm{S}_{3} \mathrm{Sn}$ are also liposoluble, but to a very different extent. Lipid partitioning is an important factor to consider when studying uptake of $\mathrm{But}_{3} \mathrm{Sn}$ in living organisms (Laughlin et al. 1986a), and the higher value of $\mathrm{k}_{12} / k_{21}$ for But 3 Sn compared to $\mathrm{MeHg}$ may reflect a partitioning of this compound preferably in compartments with a higher lipid content.

\section{CONCLUSION}

Both models developed for this study to characterize kinetics of distribution of $\mathrm{MeHg}, \mathrm{But}_{3} \mathrm{Sn}$, and inorganic $\mathrm{Hg}$ (II) and Sn(IV) are useful, as their results can be interpreted in relation to physiological characteristics of the biological model and to the physical and chemical properties of the metal species used. The 3compartment model is well adapted to starfish, as it represents a more realistic model of digestion and distribution processes of this marine animal, thus more clearly evidencing differences between metal species than the 2-compartment model. It allowed us to distinguish between 2 modes of metal transfer which differ in their mechanisms and their environment, as the transfer from Compartment $E$ to Compartment $C$ concerns the extracellular environment of the starfish, while uptake in Compartment $R$ implies transfer between extra- and intracellular environments. Such a distribution model in which compartment content is related to the whole-body content rather than the concentration in a reference tissue could be used for studies on the distribution kinetics of trace metals, organometals, and other substances (like nutrients) in other marine invertebrates, like crustaceans or molluscs. By neglecting exchanges between rectal caeca and Compartment $\mathrm{R}$, this model approximated the digestion physiology of the starfish. If necessary, the physiological significance of the model can be improved by adding a separate compartment for rectal caeca. The feeding method and the short temporal scale for this study were chosen to minimize possible metabolical variations and isolate the effects of physical and chemical properties on the distribution of the $\mathrm{Hg}$ and Sn species studied. However, it is clear that the suitability of these compartmental models for longer exposure periods using a normal mode of feeding (Leptasterias polaris feeds and digests prey by everting the stomach or having the prey in the stomach; Himmelman \& Dutil 1991) will need to be assessed.

We observed that organometal kinetics and their distribution were markedly different from those of corresponding inorganic ions. Despite the fact that $\mathrm{MeHg}$ 
and $\mathrm{But}_{3} \mathrm{Sn}$ molecules are chemically different, their similar steady-state distribution is an indication of the similarity of their amphiphilicity, as organometals share properties of both organic compounds and metallic cations. Differences observed between their distribution kinetics seem to be related to significant differences in some specific properties, like binding affinity, lipophilicity, and molecular structure.

Organometals and organometalloids are of prime environmental concern, as applications of new organosilicon, -germanium, -titanium, -zirconium, and -tin compounds are currently being studied in view of their potential use as biocides (Singh et al. 1993, Seyferth \&
Masterman 1994). Quantitative parameters characterizing the distribution and kinetics of organometais in aquatic organisms and their environment, and the establishment of relationships with the physical and chemical properties of these molecules are urgently needed.

Acknowledgements. This work was supported by the National Science and Engineering Research Council of Canada, the Fond FCAR (Québec), and the Swedish Environment Protection Board. The authors are grateful to the anonymous review ers for their useful comments which helped us to improve the original manuscript and to Agneta Boström, Claire Labrie, and Johanne Noël for their technical assistance.

\section{GLOSSARY}

\begin{tabular}{|c|c|c|c|}
\hline $\begin{array}{l}C l \\
E, C R \\
C, R\end{array}$ & $\begin{array}{l}\text { Clearance constant } \\
\text { Quantity of a given metal species in Compart- } \\
\text { ments E, CR, C, and R, respectively }\end{array}$ & $\begin{array}{l}k_{r c}, k_{\mathrm{e}} \\
V\end{array}$ & $\begin{array}{l}\text { First order rate constant characterizing excretion } \\
\text { with feces and metabolic wastes, respectively. } \\
\text { Apparent volume of distribution }\end{array}$ \\
\hline$E, C R$, & Proportion of the whole body content of & $Q$ & Whole-body content of metal \\
\hline$C, R$ & $\begin{array}{l}\text { metal species in Compartments } \mathrm{E}, \mathrm{CR}, \mathrm{C} \text {, and } \mathrm{R} \text {, } \\
\text { respectively }\end{array}$ & $Q_{0}$ & Whole-body content of metal at $t=0$ \\
\hline $\begin{array}{l}E_{\mathrm{SS}}, C R_{\mathrm{SS}} \\
\boldsymbol{C}_{\mathrm{S} S}, \boldsymbol{R}_{\mathrm{SS}}\end{array}$ & $\begin{array}{l}\text { Proportion of the whole body content of given } \\
\text { metal species in compartments } E, C R, C \text {, and R, }\end{array}$ & $\alpha_{1}$ & $\begin{array}{l}\text { Rate constant characterizing the time needed to } \\
\text { reach steady-state for the transfer of metal species } \\
\text { from Compartments } E \text { to } C R \text { or } C\end{array}$ \\
\hline $\begin{array}{l}k_{12}, k_{21} \\
k_{23}, k_{32}\end{array}$ & $\begin{array}{l}\text { respectively, when distribution is at steady-state } \\
\text { First order distribution rate constants }\end{array}$ & $\alpha_{2}$ & $\begin{array}{l}\text { Rate constant characterizing the time needed to } \\
\text { reach steady-state for the transfer of metal species } \\
\text { from Compartments } C \text { to } R\end{array}$ \\
\hline
\end{tabular}

\section{LITERATURE CITED}

Barron MG (1990) Bioconcentration. Environ Sci Technol 24: 1612-1618

Barron MG, Plakas SM, Wilga PC, Ball T (1993) Absorption, tissue distribution and metabolism of chlorpyrifos in channel catfish following waterborne exposure. Environ Toxicol Chem 12:1469-1476

Barron MG, Stehly GR, Hayton WL (1990) Pharmacokinetic modeling in aquatic animals 1 . Models and concepts. Aquat Toxicol 18:61-86

Bertram PE, Brooks AS (1986) Kinetics of accumulation of selenium from food and water by fathead minnows. Wat Res 7:877-884

Bienvenue E, Boudou A, Desmazès JP, Gavach C, Georgescauld D. Sandeaux J, Sandeaux R, Seta P (1984) Transport of mercury across bimolecular lipid membranes: effect of lipid composition, $\mathrm{pH}$ and chloride concentration. Chemico-Biol Interactions 48:91-101

Bjerrum PJ (1983) Induction of anion transport in biological membranes. In: Grandjean P, Grandjean EC (eds) Biological effects of organolead compounds. CRC Press, Boca Raton, FL, p 125-136

Bloom NS (1992) On the chemical form of mercury in edible fish and marine invertebrate tissue. Can J Fish Aquat Sci 49:1010-1017

Carty AJ, Malone SF (1979) The chemistry of mercury in biological systems. In: Nriagu JO (ed) The biogeochemistry of mercury in the environment. Elsevier, North Holland Biomedical Press, Amsterdam, p 433-479
Clark EA, Sterritt RM, Lester JN (1988) The fate of tributyltin in the aquatic environment. Environ Sci Technol 22 $600-604$

Depledge MH, Rainbow PS (1990). Models of regulation and accumulation of trace metals in marine invertebrates. Comp Biochem Physiol 97C:1-7

DiStefano JJ Ill, Landaw EM (1984) Multiexponential, multicompartmental, and noncompartmental modeling. I. Methodological limitations and physiological interpretations. Am J Physiol 246:R651-R664

Dowson PH, Bubb JM, Lester JN (1992) Organotin distribution in sediments and waters of selected east coast estuaries in the UK. Mar Pollut Bull 24:492-498

Ferguson JC (1982) Nutrient translocation. In: Jangoux M, Lawrence JM (eds) Echinoderm nutrition. AA Balkema, Rotterdam, p 373-393

Fujiki M, Tajima S (1992) The pollution of Minamata Bay by mercury. Water Sci Technol 25:133-140

Glynn AW (1991) Cadmium and zinc kinetics in fish: studies on water-borne ${ }^{109} \mathrm{Cd}$ and ${ }^{65} \mathrm{Zn}$ turnover and intracellular distribution in minnows, Phoxinus phoxinus. Pharmacol Toxicol 69:485-491

Hare L, Saouter E, Campbell PGC, Tessier A, Ribeyre F, Boudou A (1991) Dynamics of cadmium, lead, and zinc exchange between nymphs of the burrowing mayfly Hexagenia rigida (Ephemeroptera) and the environment. Can J Fish Aquat Sci 48:39-47

Himmelman JH, Dutil C (1991) Distribution, population structure and feeding of subtidal seastars in the northern Gulf of St. Lawrence. Mar Ecol Prog Ser 76:61-72 
Jangoux M, Lawrence JM (1982) Echinoderm nutrition. AA Balkema, Rotterdam

Laughlin RB Jr, French W, Guard HE (1986a) Accumulation of bis(tributyltin)oxide by the marine mussels Mytilus edulis. Environ Sci Technol 20:884-890

Laughlin RB Jr, Guard HE, Coleman WM (1986b) Tributyltin in seawater: speciation and octanol-water partition coefficient. Environ Sci Technol 20:201-204

Maheu S, Pelletier E (1994) Effects of complexing agents on the distribution of $\mathrm{Hg}$ (II) species provided by food to starfish Leptasterias polaris. Chem Speciation Bioavail 6:103-112

Major MA, Rosenblatt DH (1991) The octanol/water partition coefficient of methylmercuric chloride and methylmercuric hydroxide in pure water and salt solutions. Environ Toxicol Chem 10:5-8

Mercier A, Pelletier E, Hamel JF (1994) Metabolism and subtle effects of butyltin compounds in starfish. Aquat Toxicol 28:259-273

Musmeci MT, Madiona G, Lo Guidice MT, Silvestri A, Ruisi G, Barbieri R (1992) Interactions of organotins with biological systems. Appl organomet Chem 6:127-138

Pascal P (1963) Nouveau traité de chimie minérale, tome VIII. Masson et Cie, Paris

Pelletier E, Larocque R (1987) Bioaccumulation of mercury in starfish from contaminated mussels. Mar Pollut Bull 18 : $482-485$

Rabenstein DL, Reid RS, Isab AA (1983) ${ }^{1} \mathrm{H}$ NMR study of the effectiveness of various thiols for removal of methylmercury from hemolyzed erythrocytes. J inorg Biochem 18: $241-251$

Riisgård HU, Hansen S (1990) Biomagnification of mercury in a marine grazing food-chain: algal cells Phaeodactylum tricornutum, mussels Mytilus edulis and flounders Platichthys flesus studied by means of a stepwise-reductionCVAA method. Mar Ecol Prog Ser 62:259-270

Rothstein A (1981) Mercurials and red cell membranes. Prog

This article was presented by S. W. Fowler (Senior Editorial Advisor), Monaco clin biol Res 51:105-131

Rouleau C (1994) Cinétique d'accumulation et de distribution du méthylmercure, du tributylétain et des ions inorganiques correspondants chez l'étoile de mer (Asterias rubens et Leptasterias polaris). PhD thesis, no 11, University of Québec at Rimouski

Rouleau C, Pelletier E, Pellerin-Massicotte J (1992) Uptake of organic mercury and selenium from food by nordic shrimp Pandalus borealis. Chem Speciation Bioavail 4:75-81

Seyferth D, Masterman TC (1994) Novel polymers containing carbon-anchored organotin groups. Appl organomet Chem 8:335-350

Shin EB, Krenkel PA (1976) Mercury uptake by fish and biomethylation mechanisms. J Wat Pollut Control Fed 48 : $473-501$

Simkiss K, Taylor MG (1989) Metal fluxes across the membranes of aquatic organisms. Rev aquat Sci 1:173-188

Singh D, Kumari A, Singh RV, Mehta SM, Gupta IJ, Singh K (1993) Antifertility and biocidal activities of organometaliics of silicon, germanium, titanium and zirconium derived from 2-acetylthiophene thiosemicarbazone. Appl organomet Chem 7:289-292

Smith PJ, McVeagh M (1991) Widespread organotin pollution in New Zealand coastal waters as indicated by imposex in dogwhelks. Mar Pollut Bull 22:409-413

Spacie A, Hamelink JL (1985) Bioaccumulation. In: Rand GM, Petrocelli SR (eds) Fundamentals of aquatic toxicology. Hemisphere Publishing Corporation, New York, p 495-525

Toribara TY (1985) Preparation of $\mathrm{CH}_{3}{ }^{203} \mathrm{HgCl}$ of high specific activity. Int J Appl Radiat Isotopes 36:903-904

Ullberg S, Larsson B, Tjälve $H$ (1982) Autoradiography. In: Gleen $\mathrm{HJ}$ (ed) Biological applications of radiotracers. CRC Press, Boca Raton, FL, p 56-108

Zuolian C, Jensen A (1989) Accumulation of organic and inorganic tin in blue mussel, Mytilus edulis, under natural conditions. Mar Pollut Bull 20:281-286

Manuscript first received: June 27, 1994

Revised version accepted: February 14, 1995 